\title{
Cognitive Innovation, Irony and Collaboration
}

\author{
Michael Punt \\ Cognition Institute \\ School of Art, Design and Architecture, \\ Plymouth University, UK \\ michael.punt@plymouth.ac.uk
}

\author{
Susan L. Denham \\ Cognition Institute \\ School of Psychology, \\ Plymouth University, UK \\ sdenham@plymouth.ac.uk
}

Received 8 April 2017; accepted 26 September 2017; published 21 November 2017.

\begin{abstract}
What seems clear from the experiences of researchers in CogNovo is that the concept of cognitive innovation offered a new vocabulary, and thus a clear space, within which creativity could be explored free from the baggage of prior conflicting definitions. The concept was, from its inception, intrinsically ironic in the sense that Richard Rorty developed the term. Although initially we did not fully appreciate the potential this offered, approaching creativity under the rubric of cognitive innovation led to novel ideas that would not have emerged if we had taken a more conventional discipline-led approach. One example was expressing creativity as a mathematical function and as a media form in a parallel text. The absurdity of describing a process of such complexity in this form did not pass us by. However, this self-conscious irony, not a common rhetorical strategy in the sciences, clarified our understanding of cognitive innovation as a recursive function that allowed us to express a continuity between the basic life processes of exploration, innovation and the construction of the self, and the social and cultural ramifications of these processes; creativity. It led us to conclude that cognitive innovation furnishes a view of the self as a dynamic entity, for whom reality and novelty are contingent on one's current state, both of which can change and be changed, and offers a means for enhancing the rigor of the current debate on what counts as creative. It also reveals the value of irony in not disavowing the inevitability of multiple perspectives and prospectives on reality, and consequently offers a way to avoid unnecessary reductivism. In this paper, we will argue, as we take the insights of CogNovo forward, that irony offers a hitherto unappreciated strategy for collaborative research.
\end{abstract}

Keywords: cognitive innovation; collaboration; creativity; irony; Richard Rorty. 
DUMBY. I congratulate you, my dear fellow. In this world there are only two tragedies. One is not getting what one wants, and the other is getting it. The last is much the worst; the last is a real tragedy! But I am interested to hear she does not love you. How long could you love a woman who didn't love you, Cecil?

CECIL GRAHAM. A woman who didn't love me? Oh, all my life!

DUMBY. So could I. But it's so difficult to meet one.

LORD DARLINGTON. How can you be so conceited, Dumby?

DUMBY. I didn't say it as a matter of conceit. I said it as a matter of regret. I have been wildly, madly adored. I am sorry I have. It has been an immense nuisance. I should like to be allowed a little time to myself now and then.

LORD AUGUSTUS. [Looking round.] Time to educate yourself, I suppose.

DUMBY. No, time to forget all I have learned. That is much more important, dear Tuppy. [Lord Augustus moves uneasily in his chair.]

LORD DARLINGTON. What cynics you fellows are!

CECIL GRAHAM. What is a cynic? [Sitting on the back of the sofa.]

LORD DARLINGTON. A man who knows the price of everything and the value of nothing.

CECIL GRAHAM. And a sentimentalist, my dear Darlington, is a man who sees an absurd value in everything, and doesn't know the market price of any single thing.

LORD DARLINGTON. You always amuse me, Cecil. You talk as if you were a man of experience.

CECIL GRAHAM. I am. [Moves up to front off fireplace.]

LORD DARLINGTON. You are far too young!

CECIL GRAHAM. That is a great error. Experience is a question of instinct about life. I have got it. Tuppy hasn't. Experience is the name Tuppy gives to his mistakes. That is all. [Lord Augustus looks round indignantly.]

DUMBY. Experience is the name every one gives to their mistakes.

CECIL GRAHAM. [Standing with his back to the fireplace.] One shouldn't commit any. [Sees Lady Windermere's fan on sofa.]

DUMBY. Life would be very dull without them. 
We take our title from Richard Rorty's 1987 book, Contingency, Irony and Solidarity, which challenges the idea that epistemology will reveal reality in its fullness. The attraction of this approach to our project of developing a concept of cognitive innovation as the entrainment of two discrete systems-one cognitive and the other cultural-was that it allowed us to engage with the world and our perception of it without insisting on any ultimate reality. How, and to what extent, these two systems are entrained is, we argue, historically variable and largely a matter of the opportunities that exist in the dominant social and economic institutional structures to accommodate cultural beliefs, preferences and values. Today the research relations between reasonably codified instruments of knowledge (for example, the sciences and the arts and humanities) are determined by the institutional platforms that afford information exchange. In the case of those sciences that deal with human cognition, these have been compartmentalized in a very particular way since the beginning of the 1800s to the extent that the arts and humanities are no longer considered a reliable source of information about the human mind. The emigration of the mind from the arts may or may not have been appropriate as the science of Psychology developed, but is perhaps less helpful now as we consider a (mental) function such as creativity which is inextricably entwined with cultural and social structures. To begin we had to develop a methodological framework for collaboration on research projects between those disciplines that are primarily organized to undertake epistemological research and those that try to know the world through individual and collective sensation. And for this we revisited Contingency, Irony and Solidarity.

Rorty opens his book with a reflection on the redistribution of intellectual labor in the revolutionary fervor of the late 1700s:

About two hundred years ago, the idea that truth was made rather than found began to take hold of the imagination of Europe. The French Revolution had shown that the whole vocabulary of social relations, and the whole spectrum of social institutions, could be replaced almost overnight. This precedent made utopian politics the rule rather than the exception among intellectuals. (Rorty, 1987, p. 3)

He is careful to note a parallel Romanticist movement in the arts with a similar revolutionary spirit, pointing out that the move to thinking about art as a process of creation rather than imitation brought the arts into conflict with Enlightenment science which also claimed the authority to challenge the hegemony of Religion as the "master text." In this way, he identifies a bifurcation in philosophy between the scientifically inclined philosophies that use reason to critique human belief and those which regard the arts as responses to engagement with a reality that is nonhuman. Rorty's move in this description of the secularization of human thought and action enabled him to distinguish between World and Truth. Truth, he asserted, is a product of the human mind and is what happens when we describe the world. By investing heavily in the role of language in the construction of truth (about the world), Rorty was able to consider the historical dominance of one mode of truth over another as a matter of vocabulary and habit, captured by his notion of different "final vocabularies." 
The ironist's concern with the restraints of language, in particular, is core to our understanding of the arts as a developmental practice of civilization. A rejection of art as the exclusive handmaiden of religion stimulated new visual, musical and literary forms that were intended to compensate for the expressive boundaries of language in this project to reflect a secular concern with feeling. Michael Baxandall (1974), in Painting and Experience in Fifteenth Century Italy, argues that in its maturity, the project of the Italian Renaissance was successful because it was rooted in the experience of its patrons, who, in Rorty's terms, had a different final vocabulary. Across Europe, in the centuries that followed, that is until the Modernisms of the twentieth century, polyglot practices including the theatre, the novel, and the poem were primarily vehicles for some of the intangible aspects of being human such as perception, emotion and affect. At its most intense, the artistic concern with the human psyche found coherence across many media in Romanticism. Mario Praz (1933) in his discussion of this in The Romantic Agony claims that

[t]he word 'romantic' thus comes to be associated with another group of ideas, such as 'magic', 'suggestive', 'nostalgic' and above all with words expressing states of mind such as the German 'Sehnsucht' and the English 'wistful'.... Such ideas have this in common, that they furnish only a vague indication, leaving it to the imagination to make the final evocation.... The essence of Romanticism consequently comes to consist in that which cannot be described. The word and the form, says Schlegel in Lucinde, are only accessories. (p. 33)

The concern with the restraints of language and the ironic strategies that it provokes is most familiar in the arts, and indeed can be said to be at the core of the dominant practices of the last century. However, it is no less prevalent, if perhaps less celebrated, in the many other ways that we attempt to describe the world, including the sciences.

Many nascent sciences start with empirical observations, collections of facts about the world; consider von Humboldt's explorations in the Canaries and South America (see von Humboldt, 1814-1825/1995) or Darwin's voyage on the Beagle. Observations inevitably lead to questions of causality, and the development of theories and new vocabularies which seek to explain the observations and capture new concepts; von Humboldt's identification of ecosystems, Darwin's theory of evolution. In a sense, science recognizes all theories as approximations to the truth while at the same time believing that there is some ultimate truth (the observations) to be understood.

Neuroscience has been no different. From Cajal's investigations and wonderfully intricate drawing of neurons and glial cells, came his idea of synaptic connections between discrete neurons and the glial "glue" framework that supported functioning of the neuronal network. Modern day neuroscience is replete with better and bigger ways to image the brain at work and increasingly more nuanced ways to manipulate brain processes. Arguably the greatest challenge today lies in theoretical neuroscience and the development of comprehensive systems-level theories of brain function. In this endeavor metaphors abound, e.g., neurons and neuronal networks as electrical 
circuits, the eye as a camera, the brain as a computer, memory as a filing system; all different final vocabularies. What is not so easily recognized is the difficulty of jumping outside of whatever vocabulary is currently vogue in the field, which (often imperceptibly) conditions lines of enquiry. To follow just one strand, Hermann von Helmholtz in realizing the complexities faced by perceptual systems (clutter, ambiguity, incomplete information) suggested that perception should be understood as an inferential process (von Helmholtz, 1863/1885). Richard Gregory (1980), in the same vein, analogized perception with scientific hypothesis testing; the brain generating its best guess of external reality, evaluated and refined in the light of new evidence from the sensors. Today predictive coding-(e.g., Friston, 2005), the brain as a hierarchical generative system-is an influential theory in the neurosciences, with a new final vocabulary drawn from statistical inference; countless experiments are now interpreted in terms of predictions, prediction errors, priors, posterior probabilities and so on.

Yet investigations of perception graphically demonstrate a fundamentally ironic aspect to brain function, in Rorty's sense of the word. The perceptual systems, it would seem, explore multiple alternative interpretations of the world which are not generally available to conscious awareness, but which can be exposed under circumstances of unchanging stimulation in a phenomenon known as perceptual multistability (Leopold \& Logothetis, 1999). Originally it was found by presenting different static images to the two eyes that perceptual awareness tended to switch (quite abruptly) between the two images (Porta, 1593), and consequently became known as binocular rivalry (Breese, 1909). Since then perceptual switching has been elicited in many other ways, e.g., ambiguous form from motion, Necker cube (Leopold \& Logothetis, 1999), and modalities, e.g., auditory streaming (Pressnitzer \& Hupe, 2006), verbal transformations (Kondo \& Kashino, 2007). Although perceptual switching is highly stochastic, and individually idiosyncratic, there are common underlying characteristics that point towards the (evolutionary) importance of never fixing on any final decision regarding interpretations of reality.

Viewing the (embodied) brain as a generative system that makes predictions of future, as yet unobserved, events provides a link towards a neuroscience of anticipatory behavior, imagination and social interaction. The ability to think prospectively, to imagine other realities, to construct new truths, also underpins counterfactual thinking and creativity. In "A View from the Bridge" (Denham \& Punt, 2017) we sought to differentiate cognitive innovation (the incremental exploratory process in which individuals construct the knowledge, skills and thinking processes of the self) from creativity and the social propagation of novel ideas and artifacts. Just as the notion of predictive depth provides a measure of how far into the future an individual organism plans its behaviors (possibly a useful distinction between species), so influential depth may provide a measure of the impact of a new artifact or idea, and the ability and readiness of others engage with it. Influential depth provides a snapshot of the propagation of new information within a community; each individual processing the 
information at a rate determined by their intrinsic state. In such a dynamic system, new information (potentially) changes the system state and behavioral repertoire; neither the information nor the individuals, nor the social network remain static, and the changes wrought to the system affect the possibilities of future behavior. This is just as true of scientific discovery as of any other human activity; an experiment that exposes what is claimed to be a new truth to (scientific) knowledge affects what counts as truth in the past and the future. As such, as Rorty suggests, truth is an ironic construct in that the very idea of truth is simultaneously absolute and provisional. From this recognition, we would argue that the neuroscience of creativity, currently focusing largely on individual brain function, should adopt a broader perspective that encompasses influential depth and the recognition of the interactive constructive and filtering role played by society in the creative process; the creative ecosystem.

\section{Conclusion}

For collaboration between individuals to occur, there is a need for information to be exchanged. Inevitable differences between the multiple vocabularies of the individuals necessitate the negotiation of translations or mappings between the vocabularies before effective information exchange can take place. In a multidisciplinary project such as CogNovo, these negotiations embraced quite fundamental concerns, such as what counts as a valid research question or valid form of enquiry. Seeking an alternative to consensus, and insisting on collaboration that retained difference and disciplinary distinction, i.e., transdisciplinarity (Blassnigg \& Punt, 2013), led us to irony as a methodological tool.

If we take the pragmatic view that the way we describe the world is a product of a final vocabulary and not a consequence of the reality of the world (whatever that might be argued to be), then, Rorty asks, what is our relationship to truth when we are talking about the world, and for this question he turns to the idea of irony. In contrast to the belief in a desire to know the real essences of the world and so reflect its truth, the ironist recognizes that we are always restrained by language in anything that we explore. The ironies of CogNovo and cognitive innovation may not have been well developed when this project started in 2013, but through its research new vocabularies have been developed that, while not claiming any privileged access to truth, can be played off creatively against other vocabularies with (in Rorty's words, so strikingly close to Wilde's), "metaphors of making rather than finding, of diversification and novelty rather than convergence to the antecedently present" (Rorty, 1987, p. 77).

\section{Acknowledgements}

We would like to thank our reviewers, Dr. Hannah Drayson, Prof. Roger Malina and Michael Sonne Kristensen, for helpful comments on an earlier version of this paper. 


\section{References}

Baxandall, M. (1974). Painting and Experience in Fifteenth Century Italy. Oxford, UK: Oxford University Press.

Blassnigg, M., \& Punt, M. (2013). Transdisciplinarity: Challenges, approaches and opportunities at the cusp of history. In Steps to an Ecology of Networked Knowledge and Innovation: Enabling new forms of collaboration among sciences, engineering, arts, and design: Volume II, Meta-analyses, Abstracts, and White Papers (pp. 228-235). Cambridge, MA: MIT Press. Retrieved from http://seadnetwork.wordpress.com/draft-overview-of-areport-on-the-sead-white-papers/

Breese, B. B. (1909). Binocular rivalry. Psychological Review, 16(6), 410-415.

Darwin, C. (1859). On the origin of species. London, UK: John Murray.

Denham, S. L., \& Punt, M. (2017). Abstract of “Cognitive Innovation: A View from the Bridge." Leonardo, 50(2), 184-185. doi:10.1162/LEON_a_01386

Friston, K. (2005). A theory of cortical responses. Philosophical Transactions of the Royal Society B: Biogical Sciences, 360(1456), 815-836. doi:10.1098/rstb.2005.1622

Gregory, R. L. (1980). Perceptions as hypotheses. Philosophical Transactions of the Royal Society B: Biogical Sciences, 290(1038), 181-197.

Hodgkin, A. L. (1976). Chance and design in electrophysiology: An informal account of certain experiments on nerve carried out between 1934 and 1952. The Journal of Physiology, $263,1-21$.

Kondo, H. M., \& Kashino, M. (2007). Neural mechanisms of auditory awareness underlying verbal transformations. Neuroimage, 36(1), 123-130. doi:10.1016/j.neuroimage.2007.02.024

Leopold, D. A., \& Logothetis, N. K. (1999). Multistable phenomena: Hanging views in perception. Trends in Cognitive Sciences, 3(7), 254-264.

Porta, J. B. (1593). De refraction. Optices parte. Libri novem. Naples, Italy: Salviani.

Praz, M. (1933). The Romantic Agony. New York, NY: Oxford University Press.

Pressnitzer, D., \& Hupe, J. M. (2006). Temporal dynamics of auditory and visual bistability reveal common principles of perceptual organization. Current Biology, 16(13), 1351-1357. doi:10.1016/j.cub.2006.05.054

Rorty, R. (1987). Contingency, irony and solidarity. Cambridge, UK: Cambridge University Press.

von Helmholtz, H. (1885). On the sensations of tone as a physiological basis for the theory of music (A. J. Ellis, Trans.; $2^{\text {nd }}$ ed.). London, UK: Longmans, Green, and Co. (Original work published 1863)

von Humboldt, A. (1995). Personal narrative of a journey to the equinoctial regions of the new continent. (J. Wilson, Trans.). London, UK: Penguin Classics. (Original work published 1814-1825)

Wilde, O. (1893). Lady windemere's fan: A play about a good woman. London, UK: E. Mathews and J. Lane 